Article

\title{
Potential Antiviral Xanthones from a Coastal Saline Soil Fungus Aspergillus iizukae
}

\author{
Hui-Hui Kang ${ }^{1}$, Huai-Bin Zhang ${ }^{1}$, Mei-Jia Zhong ${ }^{1}$, Li-Ying Ma ${ }^{1}$, De-Sheng Liu ${ }^{1, *}$, \\ Wei-Zhong Liu ${ }^{1, *}$ and Hong Ren ${ }^{2}$ \\ 1 College of Pharmacy, Binzhou Medical University, Yantai 264003, China; \\ kanghuihui_1993@126.com (H.-H.K.); zhanghuaibinhua@163.com (H.-B.Z.); 18660627015@163.com (M.-J.Z.); \\ maliyingbz@163.com (L.-Y.M.) \\ 2 Beijing Higher Institution Engineering Research Center of Food Additives and Ingredients, Beijing Key \\ Laboratory of Flavor Chemistry, Beijing Laboratory for Food Quality and Safety, Beijing Technology and \\ Business University, Beijing 100048, China; renhong@th.btbu.edu.cn \\ * Correspondence: desheng_liu@sina.com or deshengliu@bzmc.edu.cn (D.-S.L.); lwz1963@163.com or \\ lwz1963@bzmc.edu.cn (W.-Z.L.); Tel.: +86-535-691-3205 (W.-Z.L.)
}

Received: 27 October 2018; Accepted: 14 November 2018; Published: 15 November 2018

\begin{abstract}
Five new (1-5) and two known xanthones (6 and 7), one of the latter (6) obtained for the first time as a natural product, together with three known anthraquinones, questin, penipurdin $\mathrm{A}$, and questinol, were isolated from the coastal saline soil-derived Aspergillus iizukae by application of an OSMAC (one strain many compounds) approach. Their structures were determined by interpretation of nuclear magnetic resonance (NMR) and high-resolution electrospray ionization mass spectroscopy (HRESIMS) data, as well as comparison of these data with those of related known compounds. Antiviral activity of xanthones 1-7 was evaluated through the cytopathic effect (CPE) inhibition assay, and compound 2 exhibited distinctly strong activity towards influenza virus (H1N1), herpes simplex virus types 1 (HSV-1) and 2 (HSV-2) with $\mathrm{IC}_{50}$ values of $44.6,21.4$, and $76.7 \mu \mathrm{M}$, respectively, which indicated that it was worth to further investigate it as a potential lead compound. The preliminary structure-activity relationship of the xanthones is discussed.
\end{abstract}

Keywords: Aspergillus iizukae; xanthones; antiviral activity; structure-activity relationship

\section{Introduction}

Aspergillus iizukae is present in various environments, such as leaves of Silybum marianum [1], sponges [2], guts of a cricket species Gryllus testaceus [3], earthworm casts and different kinds of soil [4]. Recently, Özkaya et al found that the ethyl acetate extract of a sponge-associated A. iizukae showed inhibitory effects against the aquaculture pathogens Lactococcus garvieae and Vagococcus salmoninarum [2]. Additionally, a novel flavin adenine dinucleotide-dependent glucose dehydrogenase was separated from the culture of $A$. iizukae, which was capable of catalyzing the oxidation of glucose to glucono- $\delta$-lactone [5]. Nevertheless, there are only a couple of reports on its metabolites. Up to now, four new and three known aromatic butenolides were isolated from the insect symbiont $A$. iizukae [3]. It was also reported that the endophytic $A$. iizukae from $S$. marianum could produce silybin A, silybin B and isosilybin A [1].

In our continuing search for new biologically active metabolites from fungi [6,7], the prolific fungus A. iizukae was isolated from coastal saline soil in Kenli, China. Previously, two new diphenyl derivatives and nine known compounds were obtained from it in a shaken fermentation, and six of them contain chloride atoms, that demonstrating the strain was able to utilize chlorine in the biosynthesis of its metabolites [8]. In order to obtain more halogen-containing compounds, the working 
strain was fermented statically in liquid culture medium supplemented with sodium bromide applying an OSMAC strategy. Chemical exploration of the fungal extract led to the isolation of seven xanthones $(\mathbf{1}-\mathbf{7})$ (Figure 1), including five new xanthones $(\mathbf{1}-\mathbf{5})$, one new natural product (6) previously reported as a semisynthetic compound, and a known one (7), along with three known anthraquinones. Herein, the isolation and structure elucidation of the new metabolites, along with the antiviral activity of 1-7 are reported.

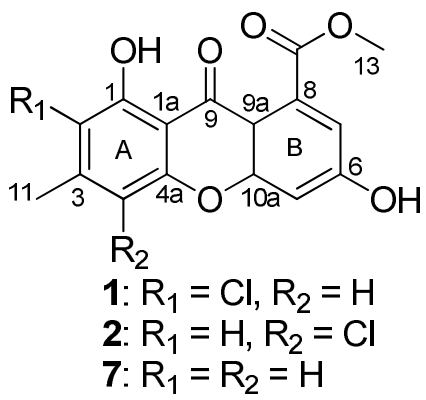<smiles>[R]c1c([R2])c2c(c(OC)c1[12H])C(=O)C1C(C(=O)OC)=CC(O)=CC1O2</smiles>

3: $\mathrm{R}_{1}=\mathrm{H}, \mathrm{R}_{2}=\mathrm{Cl}$
4: $\mathrm{R}_{1}=\mathrm{R}_{2}=\mathrm{H}$<smiles>[R]c1c([Y])c(O)c2c(c1[R])OC1C=C(O)C=C(C(=O)O)C1C2=O</smiles>

5: $\mathrm{R}_{1}=\mathrm{H}, \mathrm{R}_{2}=\mathrm{Cl}$

6: $\mathrm{R}_{1}=\mathrm{R}_{2}=\mathrm{Cl}$

Figure 1. Structures of 1-7.

\section{Results}

Compound 1 was obtained as a yellow amorphous powder. Its molecular formula $\mathrm{C}_{16} \mathrm{H}_{11} \mathrm{ClO}_{6}$, was established by the high-resolution electrospray ionization mass spectroscopy (HRESIMS) $m / z$ $335.0316[\mathrm{M}+\mathrm{H}]^{+}$, revealing eleven degrees of unsaturation. The infrared (IR) spectrum revealed the presence of hydroxy $\left(3219 \mathrm{~cm}^{-1}\right)$, conjugated ketone carbonyl $\left(1704 \mathrm{~cm}^{-1}\right)$, conjugated ester carbonyl $\left(1645 \mathrm{~cm}^{-1}\right)$, and aromatic $\left(1608,1574,1493\right.$ and $\left.1437 \mathrm{~cm}^{-1}\right)$ groups. The ultraviolet (UV) spectrum maxima at 358, 312, 290 and $237 \mathrm{~nm}$ showed typical absorptions of xanthones [9]. The ${ }^{1} \mathrm{H}$ NMR spectrum (Table 1) presented two phenolic hydroxy groups at $\delta_{\mathrm{H}} 13.00$ (br s, 1-OH) and 11.63 (br s, 6-OH), an aromatic singlet at $\delta_{\mathrm{H}} 7.12$ (s, H-4), two doublets of meta-coupled aromatic protons at $\delta_{\mathrm{H}} 6.96(\mathrm{~d}, J=2.1 \mathrm{~Hz}, \mathrm{H}-5)$ and $6.89(\mathrm{~d}, J=2.1 \mathrm{~Hz}, \mathrm{H}-7)$, one methoxy group at $\delta_{\mathrm{H}} 3.88(\mathrm{~s}, \mathrm{Me}-13)$, and one aromatic methyl group at $\delta_{\mathrm{H}} 2.46$ (s, Me-11). The ${ }^{13} \mathrm{C}$ NMR data (Table 1) displayed sixteen carbon signals, including two conjugated carbonyl groups at $\delta_{C} 178.9$ and 168.1, twelve aromatic carbon signals (three methines and four oxygenated quaternary carbons) in the region $\delta_{C}$ 103.3-164.4, one methoxy group at $\delta_{C} 52.7$ and one methyl group at $\delta_{C} 20.8$, which were clearly supported by the heteronuclear single quantum coherence (HSQC) data. The above information suggested 1 to be a chlorinated derivative of methyl-(1,6-dihydroxy-3-methylxanthone)-8-carboxylate (7) [10], which was also isolated from this culture. The positions of the carbomethoxy and hydroxy groups in ring $\mathrm{B}$ were confirmed by the correlations from H-7 to C-5, C-12 and C-9a, and from H-5 to C-6, C-7, C-9a and $\mathrm{C}-10 \mathrm{a}$ in the heteronuclear multiple bond correlation (HMBC) data (Figure 2). The chemical shift $\left(\delta_{C} 178.9\right)$ of the carbonyl (C-9) indicated the presence of a hydrogen-bonded hydroxyl group at C-1 [11,12]. Additional HMBC correlations from 1-OH to C-1, C-2 and C-1a, and from $\mathrm{H}_{3}-11$ to C-2, C-3 and C-4, placed the chlorine atom on C-2. Therefore, the structure of 1 was determined as methyl-(2-chloro-1,6-dihydroxy-3-methylxanthone)-8-carboxylate.

Compound 2 was isolated as a light-yellow powder. The HRESIMS data $\left(m / z 335.0319[\mathrm{M}+\mathrm{H}]^{+}\right)$ gave the same molecular formula $\mathrm{C}_{16} \mathrm{H}_{11} \mathrm{ClO}_{6}$ as 1 . The IR and UV data of 2 resembled those of 1, indicating that they have same scaffold. Detailed analysis and comparison of their ${ }^{1} \mathrm{H}$ and ${ }^{13} \mathrm{C}$ NMR data revealed a slight difference in the chemical shifts of ${ }^{1} \mathrm{H}$ and ${ }^{13} \mathrm{C}$ atoms in the rings $\mathrm{A}$, especially those of C-1 and C-4a, while chemical shifts in the rings B were almost identical between $\mathbf{1}$ and 2. The aforementioned data suggested that the chlorine atom was at C-4 in 2, which was confirmed by the HMBC correlations (Figure 2) from $\mathrm{H}_{3}-11$ to $\mathrm{C}-2, \mathrm{C}-3$ and $\mathrm{C}-4$, and from 1-OH to C-1, C-2 and C-1a. The other HMBC correlations shown in Figure 2 supported that the structure of 2 is methyl-(4-chloro-1,6-dihydroxy-3-methylxanthone)-8-carboxylate. 
Compound 3, a light-yellow solid, was isolated in small amount, and showed a protonated ion in its HRESIMS at $m / z 349.0476[\mathrm{M}+\mathrm{H}]^{+}$, indicating a molecular formula of $\mathrm{C}_{17} \mathrm{H}_{13} \mathrm{ClO}_{6}$ having one $\mathrm{CH}_{2}$ unit more than that of 2 . The ${ }^{1} \mathrm{H}$ and ${ }^{13} \mathrm{C}$ NMR data were very similar to those of 2 , except for the appearance of an additional methoxyl group and the disappearance of a hydroxyl group. Therefore, 3 was a methylated derivative of 2 . The lower resonance frequencies of $C-9\left(\delta_{C} 172.9\right)$ suggested that the methoxyl was at $C-1$ [13]. This hypothesis was proved by the HMBC correlations (Figure 2) from $\mathrm{H}_{3}-14$ to $\mathrm{C}-1$, and from $\mathrm{H}-2$ to $\mathrm{C}-1, \mathrm{C}-4$ and $\mathrm{C}-1 \mathrm{a}$. Based on these evidences, the structure of 3 was established as methyl-(4-chloro-6-hydroxy-1-methoxy-3-methylxanthone)-8-carboxylate.

Table 1. ${ }^{1} \mathrm{H}$ and ${ }^{13} \mathrm{C}$ NMR data for 1-3 (DMSO- $\left.d_{6}\right)$.

\begin{tabular}{|c|c|c|c|c|c|c|}
\hline \multirow{2}{*}{ Position } & \multicolumn{2}{|c|}{$1^{a}$} & \multicolumn{2}{|c|}{$2^{a}$} & \multicolumn{2}{|c|}{$3^{b}$} \\
\hline & $\delta_{C}$, type & $\delta_{H}(J$ in $\mathbf{H z})$ & $\delta_{C}$, type & $\delta_{H}(J$ in $\mathrm{Hz})$ & $\delta_{C}$, type & $\delta_{H}(J$ in $\mathrm{Hz})$ \\
\hline 1 & $155.8, \mathrm{C}$ & & $158.6, \mathrm{C}$ & & $158.4, \mathrm{C}$ & \\
\hline 2 & $113.8, \mathrm{C}$ & & $112.3, \mathrm{CH}$ & $6.83, \mathrm{~s}$ & 109.3, CH & $7.05, \mathrm{~s}$ \\
\hline 3 & 145.7, C & & $145.7, \mathrm{C}$ & & $144.2, \mathrm{C}$ & \\
\hline 4 & $108.7, \mathrm{CH}$ & $7.12, \mathrm{~s}$ & 109.7, C & & 111.0, C & \\
\hline 5 & 103.3, CH & $6.96, \mathrm{~d}(2.1)$ & 103.3, CH & 6.97, brs & 103.3, CH & $6.91, \mathrm{~d}(2.2)$ \\
\hline 6 & $164.4, \mathrm{C}$ & & $164.5, \mathrm{C}$ & & $163.3, \mathrm{C}$ & \\
\hline 7 & $113.1, \mathrm{CH}$ & $6.89, \mathrm{~d}(2.1)$ & $113.4, \mathrm{CH}$ & 6.89, brs & $113.3, \mathrm{CH}$ & $6.78, \mathrm{~d}(2.2)$ \\
\hline 8 & 135.0, C & & $135.0, \mathrm{C}$ & & $135.8, \mathrm{C}$ & \\
\hline 9 & $178.9, \mathrm{C}$ & & $178.9, \mathrm{C}$ & & $172.9, \mathrm{C}$ & \\
\hline 11 & $20.8, \mathrm{CH}_{3}$ & $2.46, \mathrm{~s}$ & $20.6, \mathrm{CH}_{3}$ & $2.43, \mathrm{~s}$ & $21.2, \mathrm{CH}_{3}$ & $2.49, \mathrm{~s}$ \\
\hline 12 & $168.1, \mathrm{C}$ & & $168.1, \mathrm{C}$ & & $169.3, \mathrm{C}$ & \\
\hline 13 & $52.7, \mathrm{CH}_{3}$ & $3.88, \mathrm{~s}$ & $52.7, \mathrm{CH}_{3}$ & $3.88, \mathrm{~s}$ & $52.9, \mathrm{CH}_{3}$ & $3.84, \mathrm{~s}$ \\
\hline 14 & & & & & $56.8, \mathrm{CH}_{3}$ & $3.88, \mathrm{~s}$ \\
\hline 1a & 106.6, C & & 107.0, C & & $112.5, \mathrm{C}$ & \\
\hline $4 a$ & 153.1, C & & $150.4, \mathrm{C}$ & & $152.4, \mathrm{C}$ & \\
\hline $9 a$ & 108.7, C & & 108.7, C & & $112.2, \mathrm{C}$ & \\
\hline $10 \mathrm{a}$ & 157.7, C & & 157.4, C & & 156.3, C & \\
\hline $\mathrm{HO}-6$ & & $11.63, \mathrm{brs}$ & & & & $11.25, \mathrm{brs}$ \\
\hline $\mathrm{HO}-1$ & & $13.00, \mathrm{~s}$ & & $12.29, \mathrm{brs}$ & & \\
\hline
\end{tabular}

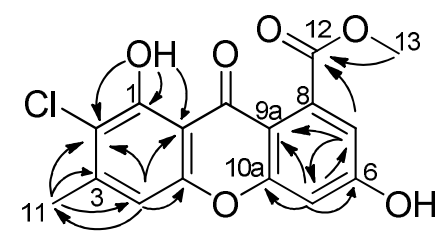

1

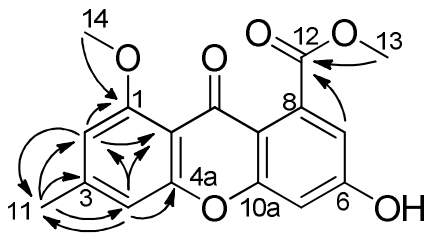

4

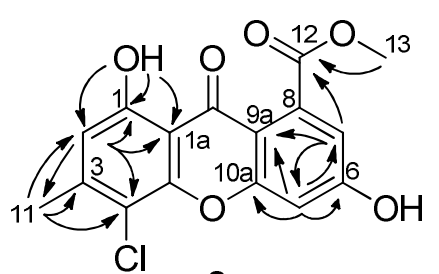

2

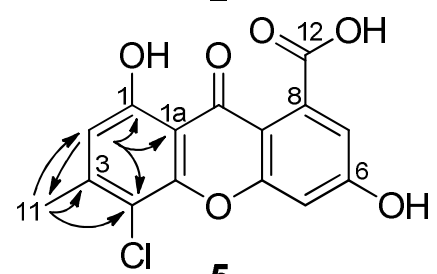

5

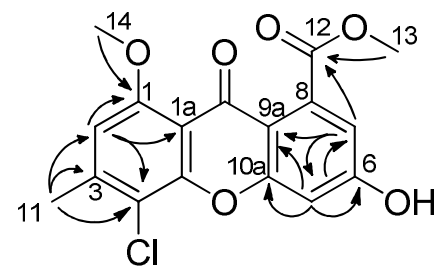

3

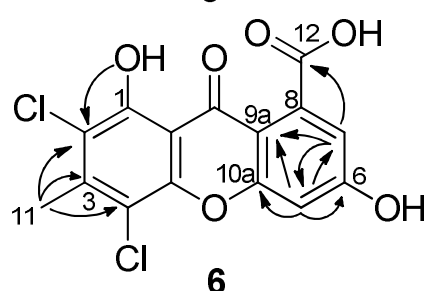

Figure 2. Selected key HMBC correlations of 1-6.

Compound 4 was obtained as an orange powder. The molecular formula was determined as $\mathrm{C}_{17} \mathrm{H}_{14} \mathrm{O}_{6}$ from the HRESIMS $m / z 313.0727[\mathrm{M}-\mathrm{H}]^{-}$, showing the absence of chlorine atoms and one hydrogen atom more than that of 3 . In the ${ }^{1} \mathrm{H}$ NMR spectrum, four broad singlets $\left(\delta_{\mathrm{H}} 6.94,6.87\right.$ 6.82 and $6.73,1 \mathrm{H}, \mathrm{s}$, each) were observed. Careful comparison of the NMR spectra data between 3 and 4 (Tables 1 and 2) revealed that it was a dechlorinated derivative of 3 . This hypothesis was 
confirmed by analysis of the HMBC correlations (Figure 2). Therefore, the structure of 4 was elucidated as methyl-(6-hydroxy-1-methoxy-3-methylxanthone)-8-carboxylate.

Table 2. ${ }^{1} \mathrm{H}$ and ${ }^{13} \mathrm{C}$ NMR data for $4-6\left({ }^{1} \mathrm{H} 400 \mathrm{MHz}\right.$ and ${ }^{13} \mathrm{C} 100 \mathrm{MHz}$ in DMSO- $\left.d_{6}\right)$.

\begin{tabular}{|c|c|c|c|c|c|c|}
\hline \multirow{2}{*}{ Position } & \multicolumn{2}{|c|}{4} & \multicolumn{2}{|c|}{5} & \multicolumn{2}{|c|}{6} \\
\hline & $\delta_{C}$, type & $\delta_{\mathbf{H}}(J$ in $\mathrm{Hz})$ & $\delta_{C}$, type & $\delta_{H}(J$ in $\mathrm{Hz})$ & $\delta_{C}$, type & $\delta_{H}(J$ in $\mathrm{Hz})$ \\
\hline 1 & $159.8, \mathrm{C}$ & & $158.7, \mathrm{C}$ & & 154.6, C & \\
\hline 2 & 107.7, CH & $6.82, \mathrm{~s}$ & $112.3, \mathrm{CH}$ & $6.85, \mathrm{~s}$ & $114.4, \mathrm{C}$ & \\
\hline 3 & $146.5, \mathrm{C}$ & & $145.6, \mathrm{C}$ & & $142.6, \mathrm{C}$ & \\
\hline 4 & 109.4, CH & $6.94, \mathrm{~s}$ & $109.6, \mathrm{C}$ & & $110.6, \mathrm{C}$ & \\
\hline 5 & $102.8, \mathrm{CH}$ & $6.87, \mathrm{~s}$ & $102.8, \mathrm{CH}$ & $6.93, \mathrm{~s}$ & 102.7, $\mathrm{CH}$ & $6.95, \mathrm{~d}(2.2)$ \\
\hline 6 & $162.5, \mathrm{C}$ & & $164.6, \mathrm{C}$ & & $164.9, \mathrm{C}$ & \\
\hline 7 & $112.2, \mathrm{CH}$ & $6.73, \mathrm{~s}$ & $112.3, \mathrm{CH}$ & $6.85, \mathrm{~s}$ & 113.1, CH & $6.86, \mathrm{~d}(2.1)$ \\
\hline 8 & $135.4, \mathrm{C}$ & & 137.4 & & 137.2, C & \\
\hline 9 & $172.7, \mathrm{C}$ & & $179.0, \mathrm{C}$ & & $178.7, \mathrm{C}$ & \\
\hline 11 & $21.8, \mathrm{CH}_{3}$ & $2.42, \mathrm{~s}$ & $20.6, \mathrm{CH}_{3}$ & $2.44, \mathrm{~s}$ & & \\
\hline 12 & $169.1, \mathrm{C}$ & & $168.9, \mathrm{C}$ & & $168.8, \mathrm{C}$ & \\
\hline 13 & $52.4, \mathrm{CH}_{3}$ & $3.84, \mathrm{~s}$ & & & $18.5, \mathrm{CH}_{3}$ & $2.56, \mathrm{~s}$ \\
\hline 14 & $56.1, \mathrm{CH}_{3}$ & $3.87, \mathrm{~s}$ & & & & \\
\hline $1 \mathrm{a}$ & $109.2, \mathrm{C}$ & & 107.0, C & & 107.1, C & \\
\hline $4 a$ & $156.9, \mathrm{C}$ & & $150.4, \mathrm{C}$ & & 149.0, C & \\
\hline $9 a$ & $112.2, \mathrm{C}$ & & 108.3, C & & 108.0, C & \\
\hline $10 a$ & 156.1, C & & $157.5, \mathrm{C}$ & & 157.5, C & \\
\hline $\mathrm{HO}-6$ & & & & $12.44, \mathrm{~s}$ & & \\
\hline $\mathrm{HO}-1$ & & & & $12.44, \mathrm{~s}$ & & $13.22, \mathrm{brs}$ \\
\hline
\end{tabular}

Compound 5 was isolated as a pale-yellow powder and had the molecular formula $\mathrm{C}_{15} \mathrm{H}_{9} \mathrm{ClO}_{6}$ as determined by the HRESIMS $m / z 319.0013[\mathrm{M}-\mathrm{H}]^{-}$. Therefore, 5 has one $\mathrm{CH}_{2}$ unit less than 2. In its IR spectrum the broad absorption at 3300-2600 $\mathrm{cm}^{-1}$, along with the absorption at $1694 \mathrm{~cm}^{-1}$, revealed the presence of a carboxylate functionality in 5. Its NMR data were very similar to those of $\mathbf{2}$, except for the absence of a methoxy group and the presence of a broad singlet of a hydroxy group in 5. In the HMBC spectrum, the correlations from H-11 to C-2, C-3 and C-4, and from H-2 to C-1, C-4, C-11 and C-1a were observed, which unequivocally established the substitution of ring A. In spite of no HMBC correlations observed from H-6 and H-7 to any carbons, the ring $\mathrm{B}$ and the chemical shift assignment of corresponding carbons and protons could be achieved by comparison of its ${ }^{1} \mathrm{H}$ and ${ }^{13} \mathrm{C}$ data with those of 6 and calyxanthone [14]. Interestingly, in the ${ }^{13} \mathrm{C}$ NMR spectrum, the resonance intensity of carbon atoms in ring B was much weaker than that of carbon atoms in ring A (Figure S30). Compound 5 was identified as 4-chloro-1,6-dihydroxy-3-methylxanthone-8-carboxylic acid.

Compound 6 was isolated as an orange-red powder and has low solubility in methanol. Its molecular formula $\mathrm{C}_{15} \mathrm{H}_{8} \mathrm{Cl}_{2} \mathrm{O}_{6}$ was determined on the basis of the HRESIMS $m / z 352.9604[\mathrm{M}-\mathrm{H}]^{-}$. The relative height of the typical isotopic ion peak (at $m / z 354.9570[\mathrm{M}-\mathrm{H}]^{-}$) was approximately two thirds of that of the quasi-molecular ion peak (Figure S40), suggesting the existence of two chlorine atoms. Its UV spectrum showed characteristic absorption bands of xanthones. In the ${ }^{1} \mathrm{H}$ NMR spectrum, the meta-coupled aromatic protons at $\delta_{\mathrm{H}} 6.95(\mathrm{~d}, J=2.2 \mathrm{~Hz}, \mathrm{H}-5)$ and $6.86(\mathrm{~d}, J=2.1 \mathrm{~Hz}$, $\mathrm{H}-7$ ) of ring B were supported by the HMBC correlations (Figure 2) from H-5 to C-6, C-7, C-9a and C-10a, and from H-7 to C-5, C-12 and C-9a, which was confirmed by similar ${ }^{1} \mathrm{H}$ and ${ }^{13} \mathrm{C}$ chemical shifts values to those of calyxanthone [14]. The downfield shift of the carbonyl implied the hydrogen bonded phenolic hydroxyl at $\delta_{\mathrm{H}} 13.22$ (br s, 1-OH) attached to C-1. Additionally, the HMBC correlations from the aromatic methyl protons to C-2, C-3 and C-4, and from 1-OH to C-2, demonstrated that chlorine atoms were both at C-4 and C-2, respectively. Ultimately, the structure of 6 was established to be 2,4-dichloro-1,6-dihydroxy-3-methylxanthone-8-carboxylic acid. Compound 6 was previously described as a synthetic intermediate using only UV and IR data [15]. This is the first report of its isolation from a natural extract. 
The known compounds were identified as methyl-(1,6-dihydroxy-3-methylxanthone)-8-carboxylate (7) [14], questin [8], penipurdin A [16], and questinol [17] by comparison of their NMR data with those reported in the literatures.

Xanthones 1-7 were screened for their antiviral activity against H1N1, HSV-1 and HSV-2 using the CPE inhibition assay (Table 3). Compounds $\mathbf{1}, \mathbf{2}$ and $\mathbf{7}$ exhibited anti-H1N1 activity with $\mathrm{IC}_{50}$ values of $133.4,54.6$ and $140.4 \mu \mathrm{M}$, respectively, while the others were inactive (ribavirin was used as the positive control, $\mathrm{IC}_{50} 101.4 \mu \mathrm{M}$ ). Compounds $\mathbf{1}, \mathbf{2}$ and $\mathbf{7}$ showed a strong anti-HSV-1 activity with $\mathrm{IC}_{50}$ values of $55.5,21.4$ and $75.7 \mu \mathrm{M}$, respectively, and the other compounds showed a moderate anti-HSV-1 activity compared with the positive control (acyclovir, $\mathrm{IC}_{50} 150.2 \mu \mathrm{M}$ ). Compounds 2 and 7 also possessed a strong anti-HSV-2 effect with $\mathrm{IC}_{50}$ values of 76.7 and $95.4 \mu \mathrm{M}$ (acyclovir as the positive control, $\left.\mathrm{IC}_{50} 128.6 \mu \mathrm{M}\right)$, respectively.

Table 3. Antiviral activity of xanthones 1-7 against H1N1, HSV-1 and HSV-2.

\begin{tabular}{|c|c|c|c|c|c|c|c|c|c|}
\hline \multirow{2}{*}{ Compounds } & \multicolumn{7}{|c|}{$\mathrm{IC}_{50}(\mu \mathrm{M})$} & \multirow{2}{*}{ Acyclovir $^{c}$} & \multirow{2}{*}{ Ribavirin $^{c}$} \\
\hline & 1 & 2 & 3 & 4 & 5 & 6 & 7 & & \\
\hline $\mathrm{H} 1 \mathrm{~N} 1^{\mathrm{a}}$ & 133.4 & 44.6 & $>200$ & $>200$ & $>200$ & $>200$ & 140.4 & & 101.4 \\
\hline HSV-1 ${ }^{b}$ & 55.5 & 21.4 & 139.4 & 157.7 & 183.3 & 144.4 & 75.7 & 150.2 & \\
\hline $\mathrm{HSV}-2^{\mathrm{b}}$ & 175.5 & 76.7 & $>200$ & 163.3 & $>200$ & $>200$ & 95.4 & 128.6 & \\
\hline
\end{tabular}

\section{Materials and Methods}

\subsection{General Experimental Procedures}

Instrumentation used to acquire UV, IR, HRESIMS, optical rotation, and 1D and 2D NMR spectra and to perform column chromatography has been previously described [6-8] A TU-1091 spectrophotometer (Beijing Purkinje General Instrument Co., Ltd., Beijing, China) was used to measure the UV spectra in $\mathrm{MeOH}$. An attenuated total reflection (ATR) method was employed to record the infrared spectra on a Nicolet 6700 spectrophotometer (Thermo Fisher Scientific, Madison, WI, USA). An Autopol V Plus digital polarimeter (Rudolph Research Analytical, Hackettstown, NJ, USA) was used to measure optical rotation. Detailed 1D and 2D NMR spectra were recorded on a Bruker AV-400 or Bruker AVIII 500 spectrometers (Bruker Biospin Group, Karlsruhe, Germany) with tetramethylsilane as an internal reference. A 1200RRLC-6520 Accurate-Mass Q-TOF LC/MS mass spectrometer (Agilent Technologies, Ltd., Palo Alto, CA, USA) was used to acquire HRESIMS spectra. HPLC purification was carried on a SHIMADZU LC-6AR (Shimadzu Corporation, Kyoto, Japan) Liquid Chromatograph equipped with an SPD-20A diode array detector, using an ODS column (HyperClone $5 \mu \mathrm{m}$ ODS $\left(\mathrm{C}_{18}\right)$, $120 \AA, 250 \mathrm{~mm} \times 10 \mathrm{~mm}$, Phenomenex; Shim-pack GIS, $5 \mu \mathrm{m} \mathrm{C}_{18}, 250 \mathrm{~mm} \times 10 \mathrm{~mm}$, Shimadzu. $4 \mathrm{~mL} / \mathrm{min})$.

\subsection{Fungal Material}

Aspergillus iizukae KL33 (GenBank accession numbers: HQ717800) was isolated from coastal saline soil in Kenli, Shandong Province of China, in August 2008. The strain was deposited at the Department of Chemistry, Binzhou Medical University, Yantai.

\subsection{Fermentation and Extraction}

A. iizukae KL33 was transferred aseptically to fresh PDA culture plates, and incubated at $28{ }^{\circ} \mathrm{C}$ for one week. Emerging fungal colonies were transferred into $500 \mathrm{~mL}$ Erlenmeyer flasks containing $180 \mathrm{~mL}$ of culture medium composed of glucose $(20 \mathrm{~g})$, maltose $(10 \mathrm{~g})$, mannitol $(10 \mathrm{~g})$, peptone $(10 \mathrm{~g})$, corn syrup $(3 \mathrm{~g}), \mathrm{KH}_{2} \mathrm{PO}_{4}(0.5 \mathrm{~g}), \mathrm{MgSO}_{4} \cdot 7 \mathrm{H}_{2} \mathrm{O}(0.3 \mathrm{~g})$, sodium glutamate $(10 \mathrm{~g})$, sodium bromide 
$(10 \mathrm{~g})$, water $(1 \mathrm{~L}$, half seawater and half tap water) and statically fermented at room temperature for 6 weeks.

$40 \mathrm{~L}$ of the fermentation broth was separated into mycelium and filtrate through cheesecloth. The filtrate was extracted three times with ethyl acetate. The mycelium was extracted with methanol for three times. The methanol solution was concentrated under reduced pressure to give an aqueous solution. The aqueous solution was extracted three more times with ethyl acetate. Both the ethyl acetate solutions were concentrated under reduced pressure to give a crude extract $(65 \mathrm{~g})$.

\subsection{Purification}

The crude extract (65 g) was fractionated into ten fractions (Frs 1-10) on a silica gel (200-300 mesh) column chromatography using a gradient of petroleum ether/chloroform (2:1, 1:1, $1: 2$, and $0: 1, v / v)$, followed by chloroform/methanol (100:1, 50:1, 10:1, and 0:1, v/v). Fr. 2 was passed through an ODS column (25-40 $\mathrm{m}$, Merck, Darmstadt, Germany) using a sequential mixture of $\mathrm{MeOH}$ and $\mathrm{H}_{2} \mathrm{O}$ as eluent from $20 \%$ to $100 \%$ to obtain nine fractions (Frs 2.1-2.9). Similarly, Fr. 5 was fractionated into eight fractions (Frs 5.1-5.8). Fr. 2.5 and Fr. 2.3 were purified by semipreparative HPLC on an ODS column (shim-pack GIS) with $\mathrm{MeOH} / 0.2 \%$ trifluoroacetic acid (TFA) aqueous solution $(v / v)(4: 1, v / v ; 4 \mathrm{~mL} / \mathrm{min})$ as the mobile phase to yield $1\left(20.3 \mathrm{mg}, t_{\mathrm{R}} 17.5 \mathrm{~min}\right)$ and 2 $\left(18.6 \mathrm{mg}, t_{\mathrm{R}} 20.5 \mathrm{~min}\right.$ ), respectively. Fr. 4 was fractionated into three fractions (Frs 4.1-4.3) by an ODS column chromatograph $\left(\mathrm{MeOH} / \mathrm{H}_{2} \mathrm{O}, 7: 3, v / v\right)$. Fr. 4.1 was chromatographied on a silica gel column chromatography $\left(\mathrm{CHCl}_{3} / \mathrm{MeOH}, 50: 1, v / v\right)$, and then purified by semipreparative HPLC on an ODS column (Phenomenex) eluted with $\mathrm{MeOH} / 0.2 \%$ TFA aqueous solution $(v / v)(70: 30, v / v$, $4 \mathrm{~mL} / \mathrm{min}$ ) to give $3\left(10.3 \mathrm{mg}, t_{\mathrm{R}} 11.9 \mathrm{~min}\right)$ and 4 (7.3 mg, $\left.t_{\mathrm{R}} 7.2 \mathrm{~min}\right)$. Fr. 6 was passed through ODS column $\left(\mathrm{MeOH} / \mathrm{H}_{2} \mathrm{O}, 1: 1, v / v\right)$, Sephadex LH-20 $(\mathrm{MeOH})$, and semipreparative HPLC [shim-pack GIS, $\mathrm{MeOH} / 0.2 \%$ TFA aqueous solution $(v / v)(70: 30, v / v ; 4 \mathrm{~mL} / \mathrm{min})]$ successively to yield $5(15.4 \mathrm{mg}$, $\left.t_{\mathrm{R}} 22.8 \mathrm{~min}\right)$. Fr. 5.5, Fr. 2.4 and Fr. 5.4 were chromatographed on Sephadex LH-20 columns eluted with $\mathrm{MeOH}$ to obtain $6(18.9 \mathrm{mg}), 7(17.5 \mathrm{mg}), \mathbf{9}(3.7 \mathrm{mg})$, respectively. Fr. 3 was purified by ODS $\left(\mathrm{MeOH} / \mathrm{H}_{2} \mathrm{O}, 7: 3, v / v\right)$ and Sephadex LH-20 columns $(\mathrm{MeOH})$ to obtain $8(17.3 \mathrm{mg})$. Fr. 5.3 was applied on Sephadex LH-20 (MeOH) column and further purified by semipreparative HPLC on an ODS column (Phenomenex) with $\mathrm{MeOH} / 0.2 \%$ TFA aqueous solution $(v / v)(55: 45, v / v ; 4 \mathrm{~mL} / \mathrm{min})$ as the eluting solvent to afford $10\left(17.0 \mathrm{mg}, t_{\mathrm{R}} 12.1 \mathrm{~min}\right)$.

Compound 1: a yellow amorphous powder; UV (MeOH) $\lambda_{\max }(\log \varepsilon) 358$ (3.92), 312 (4.09), 290 (3.97), 237 (4.46), 204 (4.29) nm; IR (ATR) $v_{\max }$ 3219, 1704, 1645, 1608, 1574, 1493, 1437, 1414, 1381, 1273, 1231, $1176,1146,1024,949,848,816,775 \mathrm{~cm}^{-1}$; HRESIMS $m / z 335.0316[\mathrm{M}+\mathrm{H}]^{+}$(calculated for $\mathrm{C}_{16} \mathrm{H}_{12} \mathrm{ClO}_{6}$, 335.0317). ${ }^{1} \mathrm{H}$ and ${ }^{13} \mathrm{C}$ NMR data: see Table 1.

Compound 2: a light-yellow powder; UV (MeOH) $\lambda_{\max }(\log \varepsilon): 360$ (3.98), 307 (4.12), 272 (4.09), 253 (4.31), 235 (4.51), 204 (4.31) nm; IR (ATR) $v_{\max }$ 3094, 2960, 1683, 1646, 1599, 1511, 1473, 1441, 1371, 1261, $1175,1152,907,882,811,766 \mathrm{~cm}^{-1}$; HRESIMS $\mathrm{m} / z 335.0319[\mathrm{M}+\mathrm{H}]^{+}$(calculated for $\mathrm{C}_{16} \mathrm{H}_{12} \mathrm{ClO}_{6}$, 335.0317). ${ }^{1} \mathrm{H}$ and ${ }^{13} \mathrm{C}$ NMR data: see Table 1.

Compound 3: a light-yellow solid; UV (MeOH) $\lambda_{\max }(\log \varepsilon)$ : 347 (3.59), 297 (3.74), 250 (3.97), 235 (4.12), 203 (4.12) nm; IR (ATR) $v_{\max } 3203,1740,1560,1584,1480,1436,1325,1225,1151,903,886,815$, $770 \mathrm{~cm}^{-1}$; HRESIMS $\mathrm{m} / z 349.0476[\mathrm{M}+\mathrm{H}]^{+}$(calculated for $\mathrm{C}_{17} \mathrm{H}_{14} \mathrm{ClO}_{6}, 349.0473$ ). ${ }^{1} \mathrm{H}$ and ${ }^{13} \mathrm{C}$ NMR data: see Table 1.

Compound 4: an orange powder; UV (MeOH) $\lambda_{\max }(\log \varepsilon)$ : 339 (3.38), 300 (3.53), 290 (3.55), 246 (3.78), 234 (3.93), 203 (3.98) nm; IR (ATR) $v_{\max } 3392,1740,1678,1620,1607,1437,1197,1135,842,822,802,724$ $\mathrm{cm}^{-1}$; HRESIMS $m / z 313.0727[\mathrm{M}-\mathrm{H}]^{-}$(calculated for $\mathrm{C}_{17} \mathrm{H}_{13} \mathrm{O}_{6}, 313.0718$ ). ${ }^{1} \mathrm{H}$ and ${ }^{13} \mathrm{C}$ NMR data: see Table 2.

Compound 5: a pale-yellow powder; UV (MeOH) $\lambda_{\max }(\log \varepsilon)$ : 355 (3.81), 306 (4.21), 250 (4.40), 237 (4.53), 204 (4.37) nm; IR (ATR) $v_{\max }$ 3101, 1694, 1644, 1607, 1558, 1506, 1475, 1239, 1149, 896, 821, 
$717 \mathrm{~cm}^{-1}$; HRESIMS $m / z 319.0013[\mathrm{M}-\mathrm{H}]^{-}$(calculated for $\left.\mathrm{C}_{15} \mathrm{H}_{8} \mathrm{ClO}_{6}, 319.0015\right) .{ }^{1} \mathrm{H}$ and ${ }^{13} \mathrm{C} \mathrm{NMR}$ data: see Table 2.

Compound 6: an orange-red powder; UV (MeOH) $\lambda_{\max }(\log \varepsilon): 361$ (3.96), 312 (4.41), 240 (4.73), 203 (4.67) nm; IR (ATR) $v_{\max } 3081,1691,1610,1575,1498,1432,1218,1156,913,883,828,778 \mathrm{~cm}^{-1}$. HRESIMS $m / z 352.9604[\mathrm{M}-\mathrm{H}]^{-}$(calculated for $\left.\mathrm{C}_{15} \mathrm{H}_{7} \mathrm{Cl}_{2} \mathrm{O}_{6}, 352.9625\right) .{ }^{1} \mathrm{H}$ and ${ }^{13} \mathrm{C}$ NMR data: see Table 2.

\subsection{Antiviral Activity}

The antiviral activity against influenza A virus (H1N1) was carried out by CPE inhibition assay as previously reported $[18,19]$. First, confluent MDCK cell monolayers and influenza virus (A/Puerto Rico/8/34 (H1N1), PR/8) were incubated together at $37^{\circ} \mathrm{C}$ for $1 \mathrm{~h}$. Then, the cells were treated with different test compounds after removing the virus dilution. After incubating at $37{ }^{\circ} \mathrm{C}$ for $48 \mathrm{~h}$, the cells were fixed with $4 \%$ formaldehyde of $100 \mu \mathrm{L}$ for $20 \mathrm{~min}$ at room temperature. Later on, the cells were stained with $0.1 \%$ crystal violet for $30 \mathrm{~min}$ after removal of the formaldehyde. Finally, the plates were washed and dried, followed by the measurement of the intensity of crystal violet staining for each well at $570 \mathrm{~nm}$ in a microplate reader (Bio-Rad, USA). Ribavirin was used as the positive control.

The anti-herpes simplex virus types 1 (HSV-1) and 2 (HSV-2) activity of $\mathbf{1 - 7}$ on Vero cells were conducted in the same way as described above [20], and acyclovir (ACV) was applied as the positive control.

\section{Conclusions}

In summary, the culture based on OSMAC strategy of the fungus A. iizukae yielded seven xanthones, including five new and one isolated for the first time as a natural product. Among them, five metabolites contain chlorine, and their structures were different from those previously reported from $A$. iizukae. From this study, it is clear that the OSMAC strategy is still a powerful tool in producing new metabolites from microorganisms. Compound 2 exhibited a strong antiviral activity against H1N1, HSV-1 and HSV-2 with $\mathrm{IC}_{50}$ values of 44.6, 21.4, and $76.7 \mu \mathrm{M}$, respectively, compared with the positive controls.

The results of antiviral activity of $1-7$ indicated that the hydroxy group at C-1 and the methyl carboxylate group at C-8 essentially contributed to the anti-H1N1, anti-HSV-1 and anti-HSV-2 activities, and the position of the chlorine atom in ring A would affect the antiviral activities. Additionally, it seemed that methylation of the hydroxy group at C-1 or replacement of methyl carboxylate at C-8 by carboxylic acid, to a large extent, lower the antiviral effect.

Xathones have attracted considerable interest for their promising biological activities and the interesting structural scaffold, which could be modified by various substituents [21,22]. Our finding suggests that 2 might be a potential anti-H1N1 lead candidate, worthy of a further pharmacological exploration.

Supplementary Materials: The following are available online at http:/ /www.mdpi.com/1660-3397/16/11/449/ s1, Figure S1: ${ }^{1} \mathrm{H}$ NMR spectrum $(400 \mathrm{MHz})$ of compound 1 in DMSO- $d_{6}$, Figure S2: ${ }^{13} \mathrm{C}$ NMR spectrum $(100 \mathrm{MHz})$ of compound 1 in DMSO- $d_{6}$, Figure S3: HSQC spectrum of compound 1 in DMSO- $d_{6}$, Figure S4: HMBC spectrum of compound 1 in DMSO- $d_{6}$, Figure S5: HRESIMS spectrum of compound 1, Figure S6: IR spectrum of compound 1, Figure S7: UV spectrum of compound 1 in $\mathrm{MeOH}$, Figure S8: ${ }^{1} \mathrm{H}$ NMR spectrum $(400 \mathrm{MHz})$ of compound 2 in DMSO- $d_{6}$, Figure S9: ${ }^{13} \mathrm{C}$ NMR spectrum $(100 \mathrm{MHz})$ of compound 2 in DMSO- $d_{6}$, Figure S10: HSQC spectrum of compound 2 in DMSO- $d_{6}$, Figure S11: HMBC spectrum of compound 2 in DMSO- $d_{6}$, Figure S12: HRESIMS spectrum of compound 2, Figure S13: IR spectrum of compound 2, Figure S14: UV spectrum of compound 2 in $\mathrm{MeOH}$, Figure S15: ${ }^{1} \mathrm{H}$ NMR spectrum $(500 \mathrm{MHz})$ of compound 3 in DMSO- $d_{6}$, Figure S16: ${ }^{13} \mathrm{C}$ NMR spectrum $(125 \mathrm{MHz})$ of compound 3 in DMSO- $d_{6}$, Figure S17: HSQC spectrum of compound 3 in DMSO- $d_{6}$, Figure S18: HMBC spectrum of compound 3 in DMSO- $d_{6}$, Figure S19: HRESIMS spectrum of compound 3, Figure S20: IR spectrum of compound 3, Figure S21: UV spectrum of compound 3 in MeOH, Figure S22: ${ }^{1} \mathrm{H}$ NMR spectrum (400 $\mathrm{MHz})$ of compound 4 in DMSO- $d_{6}$, Figure S23: ${ }^{13} \mathrm{C}$ NMR spectrum $(100 \mathrm{MHz})$ of compound 4 in DMSO- $d_{6}$, Figure S24: HSQC spectrum of compound 4 in DMSO- $d_{6}$, Figure S25. HMBC spectrum of compound 4 in DMSO- $d_{6}$, Figure S26: HRESIMS spectrum of compound 4, Figure S27: IR spectrum of compound 4, Figure S28: UV spectrum 
of compound 4 in MeOH, Figure S29: ${ }^{1} \mathrm{H}$ NMR spectrum (400 MHz) of compound 5 in DMSO- $d_{6}$, Figure S30: ${ }^{13} \mathrm{C}$ NMR spectrum $(100 \mathrm{MHz})$ of compound 5 in DMSO- $d_{6}$, Figure S31: HSQC spectrum of compound 5 in DMSO- $d_{6}$, Figure S32: HMBC spectrum of compound 5 in DMSO- $d_{6}$, Figure S33: HRESIMS spectrum of compound 5, Figure S34: IR spectrum of compound 5, Figure S35: UV spectrum of compound 5 in MeOH, Figure S36: ${ }^{1} \mathrm{H}$ NMR spectrum $(400 \mathrm{MHz})$ of compound 6 in DMSO- $d_{6}$, Figure S37: ${ }^{13} \mathrm{C}$ NMR spectrum $(100 \mathrm{MHz})$ of compound 6 in DMSO- $d_{6}$, Figure S38: HSQC spectrum of compound 6 in DMSO- $d_{6}$, Figure S39: HMBC spectrum of compound 6 in DMSO- $d_{6}$, Figure S40: HRESIMS spectrum of compound 6, Figure S41: IR spectrum of compound 6, Figure S42: UV spectrum of compound 6 in $\mathrm{MeOH}$.

Author Contributions: H.-H.K. contributed to the fermentation, purification, structural elucidation and manuscript preparation. H.-B.Z. and M.-J.Z. performed partial purification and IR and UV data acquisition experiments. H.R. guided the antivirus activity assay. W.-Z.L., L.-Y.M. and D.-S.L. participated in the design of the research and revised the manuscript.

Funding: This work was financially supported by the National Natural Science Foundation of China (No. 31270082) and Natural Science Foundation of Shandong Province, China (No. Y2008B17, 2018GSF119020).

Conflicts of Interest: The authors declare no conflict of interest.

\section{References}

1. El-Elimat, T.; Raja, H.A.; Graf, T.N.; Faeth, S.H.; Cech, N.B.; Oberlies, N.H. Flavonolignans from Aspergillus iizukae, a fungal endophyte of Milk Thistle (Silybum marianum). J. Nat. Prod. 2014, 77, $193-199$. [CrossRef] [PubMed]

2. Özkaya, F.C.; Peker, Z.; Camas, M.; Camas, A.S.; Altunok, M. Marine fungi against aquaculture pathogens and induction of the activity via co-culture. Clean-Soil Air Water 2017, 45, 1700238. [CrossRef]

3. Li, L.J.; Li, T.X.; Kong, L.Y.; Yang, M.H. Antioxidant aromatic butenolides from an insect-associated Aspergillus iizukae. Phytochem. Lett. 2016, 16, 134-140. [CrossRef]

4. Hubka, V.; Nováková, A.; Kolařík, M.; Jurjević, Ž.; Peterson, S.W. Revision of Aspergillus section Flavipedes: seven new species and proposal of section Jani sect. nov. Mycologia 2014, 107, 169-208. [CrossRef] [PubMed]

5. Nishio, K.; Kojima, Y.; Yamaguchi, S. Novel Flavin Adenine Dinucleotide-Dependent Glucose Dehydrogenase from Aspergillus iizukae for Highly Glucose-Specific and $\mathrm{pH}$-Stable Performance in Glucose Sensor. Patent No. WO2017077924A1, 11 May 2017.

6. Ma, L.Y.; Liu, D.S.; Li, D.G.; Huang, Y.L.; Kang, H.H.; Wang, C.H.; Liu, W.Z. Pyran rings containing polyketides from Penicillium raistrickii. Mar. Drugs 2017, 15, 2. [CrossRef] [PubMed]

7. Liu, D.S.; Huang, Y.L.; Li, C.M.; Ma, L.Y.; Pan, X.H.; Ferreira, D.; Liu, W.Z. A new sesquiterpenoid derivative from the coastal saline soil fungus Aspergillus fumigates. Rec. Nat. Prod. 2016, 10, 708-713.

8. Liu, D.S.; Yan, L.; Ma, L.Y.; Huang, Y.L.; Pan, X.H.; Liu, W.Z. Diphenyl derivatives from coastal saline soil fungus Aspergillus iizukae. Arch. Pharm. Res. 2015, 38, 1038-1043. [CrossRef] [PubMed]

9. Wang, Y.; Wang, S.S.; Zhou, D.H.; Xiao, H.B. Spectral characteristics of phytoxanthones. Nat. Prod. Res. Dev. 2002, 14, 85-90. [CrossRef]

10. Ngan, N.T.T.; Quang, T.H.; Kim, K.W.; Kim, H.J.; Sohn, J.H.; Kang, D.G.; Lee, H.S.; Kim, Y.C.; Oh, H. Anti-inflammatory effects of secondary metabolites isolated from the marine-derived fungal strain Penicillium sp. SF-5629. Arch. Pharm. Res. 2017, 40, 328-337. [CrossRef] [PubMed]

11. Li, H.L.; Li, X.M.; Liu, H.; Meng, L.H.; Wang, B.G. Two new diphenylketones and a new xanthone from Talaromyces islandicus EN-501, an endophytic fungus derived from the marine red alga Laurencia okamurai. Mar. Drugs 2016, 14, 223. [CrossRef] [PubMed]

12. Wang, Y.C.; Zheng, Z.H.; Liu, S.C.; Zhang, H.; Li, E.; Guo, L.D.; Che, Y.S. Oxepinochromenones, furochromenone, and their putative precursors from the endolichenic fungus Coniochaeta sp. J. Nat. Prod. 2010, 73, 920-924. [CrossRef] [PubMed]

13. Healy, P.C.; Hocking, A.; Tran-Dinh, N.; Pitt, J.I.; Shivas, R.G.; Mitchell, J.K.; Kotiw, M.; Davis, R.A. Xanthones from a microfungus of the genus Xylaria. Phytochemistry 2004, 65, 2373-2378. [CrossRef] [PubMed]

14. Siddiqui, I.N.; Zahoor, A.; Hussain, H.; Ahmed, I.; Ahmad, V.U.; Padula, D.; Draeger, F.; Schulz, B.; Meier, K.; Steinert, M.; et al. Diversonol and blennolide derivatives from the endophytic fungus Microdiplodia sp.: absolute configuration of diversonol. J. Nat. Prod. 2011, 74, 365-373. [CrossRef] [PubMed] 
15. Barton, D.H.R.; Scott, A.I. The constitutions of geodin and erdin. J. Chem. Soc. 1958, 1767-1772. [CrossRef]

16. Xue, J.H.; Fu, Y.; Wu, P.; Xu, L.X.; Huang, R.M.; Wei, X.Y.; Li, H.X. Two new anthraquinones from the soil fungus Penicillium purpurogenum SC0070. J. Antibiot. 2015, 68, 598-599. [CrossRef] [PubMed]

17. Zhao, D.; Cao, F.; Guo, X.J.; Zhang, Y.R.; Kang, Z.J.; Zhu, H.J. Antibacterial indole alkaloids and anthraquinones from a sewage-derived fungus Eurotium sp. Chem. Nat. Compd. 2018, 54, 399-401. [CrossRef]

18. Peng, J.X.; Zhang, X.M.; Du, L.; Wang, W.; Zhu, T.J.; Gu, Q.Q.; Li, D.H. Sorbicatechols A and B, antiviral sorbicillinoids from the marine-derived fungus Penicillium chrysogenum PJX-17. J. Nat. Prod. 2014, 77, 424-428. [CrossRef] [PubMed]

19. Peng, J.X.; Zhang, X.M.; Wang, W.; Zhu, T.J.; Gu, Q.Q.; Li, D.H. Austalides S-U, new meroterpenoids from the sponge-derived fungus Aspergillus aureolatus HDN14-107. Mar. Drugs 2016, 14, 131. [CrossRef] [PubMed]

20. Pertino, M.W.; Petrera, E.; Alché, L.E.; Schmeda-Hirschmann, G. Synthesis, antiviral and cytotoxic activity of novel terpenyl hybrid molecules prepared by click chemistry. Molecules 2018, 23, 1343. [CrossRef] [PubMed]

21. Shagufta; Ahmad, I. Recent insight into the biological activities of synthetic xanthone derivatives. Eur. J. Med. Chem. 2016, 116, 267-280. [CrossRef] [PubMed]

22. Santos, C.M.M.; Freitas, M.; Fernandes, E. A comprehensive review on xanthone derivatives as $\alpha$-glucosidase inhibitors. Eur. J. Med. Chem. 2018, 157, 1460-1479. [CrossRef] [PubMed]

(C) 2018 by the authors. Licensee MDPI, Basel, Switzerland. This article is an open access article distributed under the terms and conditions of the Creative Commons Attribution (CC BY) license (http:/ / creativecommons.org/licenses/by/4.0/). 